\title{
THE SIGNIFICANCE OF PROPERTY SECTOR AND \\ GEOGRAPHIC DIVERSIFICATION IN AUSTRALIAN \\ INSTITUTIONAL PROPERTY PORTFOLIOS
}

\section{GRAEME NEWELL and TAN YEN KENG \\ University of Western Sydney}

\begin{abstract}
In a property portfolio, the standard strategies for portfolio diversification and risk reduction are diversification by property type and geographic region, with such property investment strategies typically employed by the major institutional investors. Using the Property Council of Australia (PCA) property indices over 1995-2002, the effectiveness of these property portfolio diversification strategies is assessed for Australian institutional property portfolios. Both property type and geographic diversification are seen to deliver significant diversification benefits, with these geographic diversification benefits confirming the successful sectorspecific strategy adopted by many listed property trusts in recent years.
\end{abstract}

Keywords: Property sector diversification, geographic diversification, pure property returns, PCA property index, correlations, tracking error, sector-specific LPTs.

\section{INTRODUCTION}

In a property portfolio, the standard strategies for portfolio diversification and risk reduction are diversification by property type and geographic region, with economic diversification also offering potential diversification benefits (Lee and Byrne, 1998; Mueller, 1993; Mueller and Ziering, 1992). As evidenced in industry surveys, such property investment strategies, involving diversification by property type and geographic region, are typically employed by the major institutional investors (DeWitt, 1996; Louargard, 1992; Webb, 1984).

In Australia, the extent of these portfolio diversification strategies by listed property trusts (LPTs) in 2001 is shown in Table 1. Accounting for a property portfolio of $\$ 14.9$ billion (PIR, 2002), these nine diversified LPTs represent $36 \%$ of the total LPT sector market capitalisation (UBS Warburg, 2002) and demonstrate significant portfolio diversification across the major property sectors and geographic regions. Overall, office (51\%), retail (31\%) and industrial (13\%) are the major property sectors and NSW (49\%), Victoria (15\%) and Queensland $(15 \%)$ are the major geographic regions. 
Table 1: Diversified LPTs property diversification strategies: December 2001

\begin{tabular}{|c|c|c|c|c|c|c|c|c|}
\hline \multirow{2}{*}{ LPT } & \multirow{2}{*}{$\begin{array}{l}\text { Value of } \\
\text { property } \\
\text { portfolio }\end{array}$} & \multicolumn{7}{|c|}{ Portfolio composition (\%) } \\
\hline & & Office & Retail & Industrial & al Hotel & $\operatorname{Re}$ & dential & Other \\
\hline General Property Trust & $\$ 5,655 \mathrm{M}$ & $38 \%$ & $52 \%$ & $2 \%$ & $8 \%$ & & $0 \%$ & $0 \%$ \\
\hline Stockland Trust Group & $\$ 2,540 \mathrm{M}$ & $35 \%$ & $31 \%$ & $15 \%$ & $2 \%$ & & $17 \%$ & $0 \%$ \\
\hline Mirvac Group & $\$ 1,552 \mathrm{M}$ & $69 \%$ & $22 \%$ & $9 \%$ & $0 \%$ & & $0 \%$ & $0 \%$ \\
\hline Colonial First State & $\$ 1,688 \mathrm{M}$ & $45 \%$ & $32 \%$ & $23 \%$ & $0 \%$ & & $0 \%$ & $0 \%$ \\
\hline AMP Diversified & $\$ 1,517 \mathrm{M}$ & $48 \%$ & $43 \%$ & $9 \%$ & $0 \%$ & & $0 \%$ & $0 \%$ \\
\hline Deutsche Diversified * & $\$ 1,290 \mathrm{M}$ & $28 \%$ & $33 \%$ & $23 \%$ & $0 \%$ & & $0 \%$ & $16 \%$ \\
\hline Tyndall Meridan & $\$ 423 \mathrm{M}$ & $37 \%$ & $40 \%$ & $21 \%$ & $2 \%$ & & $0 \%$ & $0 \%$ \\
\hline James Fielding & $\$ 106 \mathrm{M}$ & $77 \%$ & $23 \%$ & $0 \%$ & $0 \%$ & & $0 \%$ & $0 \%$ \\
\hline Flexi Property & $\$ 108 \mathrm{M}$ & $84 \%$ & $0 \%$ & $16 \%$ & $0 \%$ & & $0 \%$ & $0 \%$ \\
\hline Total & $\$ 14,879 \mathrm{M}$ & $51 \%$ & $31 \%$ & $13 \%$ & $1 \%$ & & $2 \%$ & $2 \%$ \\
\hline \multicolumn{9}{|c|}{ PANEL B: GEOGRAPHIC DIVERSIFICATION } \\
\hline \multirow{2}{*}{ LPT } & \multirow{2}{*}{$\begin{array}{l}\text { Value of } \\
\text { property } \\
\text { portfolio }\end{array}$} & \multicolumn{7}{|c|}{ Portfolio composition (\%) } \\
\hline & & NSW & VIC & QLD & SA & WA & ACT & Other \\
\hline General Property Trust & $\$ 5,655 \mathrm{M}$ & $49 \%$ & $23 \%$ & $8 \%$ & $0 \%$ & $3 \%$ & $7 \%$ & $10 \%$ \\
\hline Stockland Trust Group & $\$ 2,540 \mathrm{M}$ & $60 \%$ & $11 \%$ & $16 \%$ & $4 \%$ & $4 \%$ & $4 \%$ & $1 \%$ \\
\hline Mirvac Group & $\$ 1,552 \mathrm{M}$ & $66 \%$ & $14 \%$ & $7 \%$ & $0 \%$ & $0 \%$ & $13 \%$ & $0 \%$ \\
\hline Colonial First State & $\$ 1,688 \mathrm{M}$ & $45 \%$ & $17 \%$ & $19 \%$ & $11 \%$ & $7 \%$ & $1 \%$ & $0 \%$ \\
\hline AMP Diversified & $\$ 1,517 \mathrm{M}$ & $64 \%$ & $11 \%$ & $5 \%$ & $8 \%$ & $12 \%$ & $0 \%$ & $0 \%$ \\
\hline Deutsche Diversified & $\$ 1,290 \mathrm{M}$ & $34 \%$ & $28 \%$ & $6 \%$ & $13 \%$ & $19 \%$ & $0 \%$ & $0 \%$ \\
\hline Tyndall Meridan & $\$ 423 \mathrm{M}$ & $57 \%$ & $3 \%$ & $29 \%$ & $0 \%$ & $0 \%$ & $11 \%$ & $0 \%$ \\
\hline James Fielding & $106 \mathrm{M}$ & $0 \%$ & $14 \%$ & $42 \%$ & $21 \%$ & $23 \%$ & $0 \%$ & $0 \%$ \\
\hline Flexi Property & $108 \mathrm{M}$ & $65 \%$ & $11 \%$ & $0 \%$ & $24 \%$ & $0 \%$ & $0 \%$ & $0 \%$ \\
\hline Total & $\$ 14,879 M$ & $49 \%$ & $15 \%$ & $15 \%$ & $9 \%$ & $8 \%$ & $4 \%$ & $0 \%$ \\
\hline
\end{tabular}

Source: Author's compilation from PIR (2002)

Similarly, Table 2 shows the geographic diversification strategies adopted by the sector-specific LPTs in 2001. With a property portfolio of nearly $\$ 37$ billion (PIR, 2002), these 24 sector-specific LPTs show extensive geographic diversification. The recent trend for LPTs to expand their portfolios geographically by including international property is shown by those sectorspecific LPTs including international property within their domestic property portfolios (e.g. Macquarie CountryWide, Westfield, Macquarie Goodman Industrial), as well as those setting up as separate international portfolio LPTs (e.g. Westfield America, Lend Lease US Office). 
Table 2: Sector-specific LPT geographic diversification strategies: December 2001

\begin{tabular}{|c|c|c|c|c|c|c|c|c|c|c|}
\hline \multirow[b]{2}{*}{ LPT } & \multirow{2}{*}{$\begin{array}{c}\text { Value of property } \\
\text { portfolio }\end{array}$} & \multirow{2}{*}{$\begin{array}{c}\text { \# of } \\
\text { properties }\end{array}$} & \multicolumn{8}{|c|}{ Portfolio composition (\%) } \\
\hline & & & NSW & VIC & QLD & SA & WA & ACT & Inter. & Other \\
\hline \multicolumn{11}{|l|}{ Retail LPTs } \\
\hline AMP Shopping Centre & $\$ 1,255 \mathrm{M}$ & 9 & $45 \%$ & $9 \%$ & $31 \%$ & $8 \%$ & $7 \%$ & $0 \%$ & $0 \%$ & $0 \%$ \\
\hline Bunnings Warehouse & $\$ 289 \mathrm{M}$ & 35 & $3 \%$ & $51 \%$ & $17 \%$ & $6 \%$ & $20 \%$ & $3 \%$ & $0 \%$ & $0 \%$ \\
\hline Carindale & $\$ 225 \mathrm{M}$ & 1 & $0 \%$ & $0 \%$ & $100 \%$ & $0 \%$ & $0 \%$ & $0 \%$ & $0 \%$ & $0 \%$ \\
\hline Centro Properties & $\$ 1,190 \mathrm{M}$ & 21 & $25 \%$ & $46 \%$ & $14 \%$ & $0 \%$ & $15 \%$ & $0 \%$ & $0 \%$ & $0 \%$ \\
\hline Gandel Retail & $\$ 1,962 \mathrm{M}$ & 12 & $6 \%$ & $62 \%$ & $25 \%$ & $3 \%$ & $0 \%$ & $0 \%$ & $0 \%$ & $4 \%^{(1)}$ \\
\hline Homemaker & $\$ 266 \mathrm{M}$ & 12 & $24 \%$ & $13 \%$ & $63 \%$ & $0 \%$ & $0 \%$ & $0 \%$ & $0 \%$ & $0 \%$ \\
\hline Macquarie CountryWide & $\$ 703 \mathrm{M}$ & 90 & $33 \%$ & $12 \%$ & $23 \%$ & $2 \%$ & $9 \%$ & $0 \%$ & $18 \%$ & $3 \%^{(1)}$ \\
\hline Prime Retail & $\$ \quad 227 \mathrm{M}$ & 17 & $16 \%$ & $33 \%$ & $32 \%$ & $11 \%$ & $2 \%$ & $6 \%$ & $0 \%$ & $0 \%$ \\
\hline Westfield & $\$ 7,500 \mathrm{M}$ & 40 & $43 \%$ & $14 \%$ & $13 \%$ & $6 \%$ & $10 \%$ & $2 \%$ & $12 \%{ }^{(3)}$ & $0 \%$ \\
\hline Westfield America & $\$ 9,519 \mathrm{M}$ & 39 & $0 \%$ & $0 \%$ & $0 \%$ & $0 \%$ & $0 \%$ & $0 \%$ & $100 \%{ }^{(4)}$ & $0 \%$ \\
\hline \multicolumn{11}{|l|}{ Office LPTs } \\
\hline AMP Office & $\$ 1,402 \mathrm{M}$ & 11 & $61 \%$ & $21 \%$ & $14 \%$ & $0 \%$ & $0 \%$ & $4 \%$ & $0 \%$ & $0 \%$ \\
\hline Australian Growth & $\$ 453 \mathrm{M}$ & 5 & $90 \%$ & $2 \%$ & $0 \%$ & $0 \%$ & $0 \%$ & $8 \%$ & $0 \%$ & $0 \%$ \\
\hline BT Office & $\$ 1,679 \mathrm{M}$ & 11 & $67 \%$ & $24 \%$ & $0 \%$ & $0 \%$ & $8 \%$ & $0 \%$ & $0 \%$ & $0 \%$ \\
\hline Commonwealth Property Office & $\$ 795 \mathrm{M}$ & 9 & $65 \%$ & $24 \%$ & $0 \%$ & $3 \%$ & $0 \%$ & $8 \%$ & $0 \%$ & $0 \%$ \\
\hline Deutsche Office & $\$ 1,900 \mathrm{M}$ & 11 & $79 \%$ & $17 \%$ & $0 \%$ & $0 \%$ & $2 \%$ & $2 \%$ & $0 \%$ & $0 \%$ \\
\hline ING Office & $\$ 1,216 \mathrm{M}$ & 16 & $47 \%$ & $19 \%$ & $21 \%$ & $0 \%$ & $4 \%$ & $7 \%$ & $0 \%$ & $2 \%^{(1)}$ \\
\hline Investa Property & $\$ 1,092 \mathrm{M}$ & 20 & $65 \%$ & $16 \%$ & $10 \%$ & $2 \%$ & $2 \%$ & $5 \%$ & $0 \%$ & $0 \%$ \\
\hline Lend Lease US Office & $\$ 601 \mathrm{M}$ & 8 & $0 \%$ & $0 \%$ & $0 \%$ & $0 \%$ & $0 \%$ & $0 \%$ & $100 \%^{(4)}$ & $0 \%$ \\
\hline Macquarie Office & $\$ 1,002 \mathrm{M}$ & 20 & $44 \%$ & $34 \%$ & $3 \%$ & $5 \%$ & $9 \%$ & $4 \%$ & $0 \%$ & $1 \%{ }^{(2)}$ \\
\hline \multicolumn{11}{|l|}{ Industrial LPTs } \\
\hline AMP Industrial & $\$ 463 \mathrm{M}$ & 26 & $75 \%$ & $12 \%$ & $7 \%$ & $4 \%$ & $2 \%$ & $0 \%$ & $0 \%$ & $0 \%$ \\
\hline Deutsche Industrial & $\$ 528 \mathrm{M}$ & 45 & $81 \%$ & $4 \%$ & $10 \%$ & $0 \%$ & $5 \%$ & $0 \%$ & $0 \%$ & $0 \%$ \\
\hline ING Industrial & $\$ 1,023 \mathrm{M}$ & 55 & $62 \%$ & $26 \%$ & $11 \%$ & $1 \%$ & $0 \%$ & $0 \%$ & $0 \%$ & $0 \%$ \\
\hline Macquarie Goodman Industrial & $\$ 1,146 \mathrm{M}$ & 54 & $82 \%$ & $14 \%$ & $2 \%$ & $0 \%$ & $1 \%$ & $0 \%$ & $1 \%{ }^{(3)}$ & $0 \%$ \\
\hline \multicolumn{11}{|l|}{ Hotel LPTs } \\
\hline Grand Hotel & $\$ 561 \mathrm{M}$ & 6 & $14 \%$ & $45 \%$ & $3 \%$ & $11 \%$ & $17 \%$ & $10 \%$ & $0 \%$ & $0 \%$ \\
\hline TOTAL & $\$ 36,997 \mathrm{M}$ & 573 & $43 \%$ & $21 \%$ & $17 \%$ & $3 \%$ & $5 \%$ & $2 \%$ & $10 \%$ & $<1 \%$ \\
\hline
\end{tabular}

Source: Author's compilation from PIR (2002) 
The strategic issues of property type and geographic diversification have been substantial areas of property research in recent years (see Hamelink et al, 2000; Lee and Byrne, 1998; Seiler et al, 1998 for extensive literature reviews of this area). A range of techniques have been used to assess these diversification benefits, including correlations, efficient frontiers and cluster analysis. Whilst differences in diversification benefits exist across different property markets (Eichholtz et al, 1995), the consensus view has been that property sector diversification is more effective than geographic diversification (Fisher and Liang, 2000; Lee, 2001) and hence, property sector diversification should form the first strategic level of property portfolio construction (Lee, 2001).

While the relative importance of property sector and geographic diversification has been assessed for the USA (Fisher and Liang, 2000) and the UK (Lee, 2001), the effectiveness of these property portfolio diversification strategies for Australian institutional investors also needs to be critically assessed; in particular, whether property type diversification is more effective than geographic diversification. This is particularly important, given the significant role of property in institutional portfolios in Australia, which currently sees property (both direct and indirect) accounting for $8 \%$ of institutional asset allocations in Australia (Armytage, 2002).

The purpose of this paper is to use the Property Council of Australia (PCA) property indices over 1995-2002 to assess the relative importance of property sector and geographic diversification for Australian institutional property portfolios.

\section{METHODOLOGY}

\section{Data sources}

To assess Australian property sector and geographic diversification benefits, quarterly total returns over March 1995-June 2002 were obtained (Property Council of Australia, 2002) for each of the following nine (9) commercial property markets:

- Sydney: CBD office, retail, industrial

- Melbourne: CBD office, retail, industrial

- Brisbane: CBD office, retail, industrial,

thus enabling a three sector $\mathrm{x}$ three regions comparison. Other regions (e.g. Adelaide, Perth) were excluded, as industrial property performance series are not maintained by the PCA in these regions.

Whilst the overall PCA performance indices are available from June 1985, the lesser availability of Melbourne industrial (since March 1995) and Brisbane industrial (since June 1994) limits the quarterly sector $\mathrm{x}$ region analysis to the $7 \frac{1}{2}$ 
- year period of March 1995-June 2002. Table 3 presents the number of properties and property portfolio value for each of these property markets over this period. At June 2002, these property markets represented 450 properties $(68 \%$ of the 664 properties in the overall PCA index portfolio) and $\$ 39.6 \mathrm{~B}(80 \%$ of the $\$ 49.4 \mathrm{~B}$ value of the overall PCA index portfolio), with intervening quarters also well represented in terms of this property portfolio.

Table 3: PCA index portfolio: December 1994 - June 2002

\begin{tabular}{lcccc}
\hline Property portfolio & \multicolumn{2}{c}{ December 1994 } & \multicolumn{2}{c}{ June 2002 } \\
component & \# properties & Value & \# properties & Value \\
\hline Sydney CBD office & 86 & $\$ 7.3 \mathrm{~B}$ & 66 & $\$ 12.3 \mathrm{~B}$ \\
Sydney retail & 62 & $\$ 4.2 \mathrm{~B}$ & 64 & $\$ 7.8 \mathrm{~B}$ \\
Sydney industrial & 90 & $\$ 0.9 \mathrm{~B}$ & 98 & $\$ 2.0 \mathrm{~B}$ \\
Melbourne CBD office & 54 & $\$ 3.6 \mathrm{~B}$ & 21 & $\$ 3.6 \mathrm{~B}$ \\
Melbourne retail & 24 & $\$ 2.1 \mathrm{~B}$ & 49 & $\$ 5.7 \mathrm{~B}$ \\
Melbourne industrial & 24 & $\$ 0.3 \mathrm{~B}$ & 45 & $\$ 0.6 \mathrm{~B}$ \\
Brisbane CBD office & 33 & $\$ 1.8 \mathrm{~B}$ & 32 & $\$ 2.0 \mathrm{~B}$ \\
Brisbane retail & 27 & $\$ 2.1 \mathrm{~B}$ & 49 & $\$ 5.3 \mathrm{~B}$ \\
Brisbane industrial & 11 & $\$ 0.1 \mathrm{~B}$ & 26 & $\$ 0.3 \mathrm{~B}$ \\
\hline Total portfolio & $\mathbf{4 1 1}$ & $\mathbf{\$ 2 2 . 4 B}$ & $\mathbf{4 5 0}$ & $\mathbf{\$ 3 9 . 6 B}$ \\
Total PCA portfolio & $\mathbf{6 4 0}$ & $\mathbf{\$ 2 9 . 9 B}$ & $\mathbf{6 6 4}$ & $\mathbf{\$ 4 9 . 4 B}$ \\
Percentage of total & $\mathbf{6 4 \%}$ & $\mathbf{7 5 \%}$ & $\mathbf{6 8 \%}$ & $\mathbf{8 0 \%}$ \\
PCA portfolio & & & & \\
\hline
\end{tabular}

For tracking error benchmarking purposes, the PCA "Australian" composite property portfolio returns and PCA "Sydney/Melbourne/Brisbane X Office/Retail/Industrial" composite property portfolio returns were utilised.

\section{Constructing "pure" property sector and geographic returns}

To assess the relative benefits of property sector versus geographic diversification, it is necessary to establish "pure" property sector and "pure" regional returns. Typically, the property sector and regional returns (eg: PCA, NCREIF) are not "pure", as regional returns are influenced by sector returns, as well as sector returns complicated by regional returns (Fisher and Liang, 2000).

To construct the respective pure property returns and separate the sector and regional effects, the decomposition methodology of Heston and Rouwenhorst (1994) was used. For each quarter, this model is:

$$
R_{i j}=\alpha+\beta_{O} * D_{O}+\beta_{R} * D_{R}+\beta_{I}^{*} D_{I}+\delta_{S} * D_{S}+\delta_{M} * D_{M}+\delta_{B} * D_{B}
$$


where:

$$
\begin{aligned}
& R_{i j}=\text { return for property type } i \text { in region } j \\
& \alpha=\text { market return } \\
& \beta_{O}, \beta_{R}, \beta_{I}=\text { excess property sector returns } \\
& D_{O}, D_{R}, D_{I}=\text { property sector dummy variables } \\
& \delta_{S}, \delta_{M}, \delta_{B}=\text { excess regional returns } \\
& D_{S}, D_{M}, D_{B}=\text { regional dummy variables. }
\end{aligned}
$$

This methodology can be used to generate pure property returns on both an equalweighted and value-weighted basis, using the Solver routine in Excel. To construct the equal-weighted returns, this model was subject to the two constraints:

$$
\beta_{\mathrm{O}}+\beta_{\mathrm{R}}+\beta_{\mathrm{I}}=0 \quad \text { and } \quad \delta_{\mathrm{S}}+\delta_{\mathrm{M}}+\delta_{\mathrm{B}}=0
$$

whilst for the value-weighted returns, the model was subject to the two constraints:

$$
\mathrm{w}_{\mathrm{O}} \beta_{\mathrm{O}}+\mathrm{w}_{\mathrm{R}} \beta_{\mathrm{R}}+\mathrm{w}_{\mathrm{I}} \beta_{\mathrm{I}}=0 \quad \text { and } \quad \mathrm{w}_{\mathrm{S}} \delta_{\mathrm{S}}+\mathrm{w}_{\mathrm{M}} \delta_{\mathrm{M}}+\mathrm{w}_{\mathrm{B}} \delta_{\mathrm{B}}=0
$$

where:

$\mathrm{w}_{\mathrm{O}}, \mathrm{w}_{\mathrm{R}}, \mathrm{w}_{\mathrm{I}}=$ respective property sector market shares $\left(\mathrm{w}_{\mathrm{O}}+\mathrm{w}_{\mathrm{R}}+\mathrm{w}_{\mathrm{I}}=1\right)$

$\mathrm{w}_{\mathrm{S}}, \mathrm{w}_{\mathrm{M}}, \mathrm{w}_{\mathrm{B}}=$ respective regional market shares $\left(\mathrm{w}_{\mathrm{S}}+\mathrm{w}_{\mathrm{M}}+\mathrm{w}_{\mathrm{B}}=1\right)$.

For each quarter, the resulting pure sector returns were:

Office: $\alpha+\beta_{\text {O }}$

Retail: $\alpha+\beta_{R}$

Industrial: $\alpha+\beta_{\mathrm{I}}$

and the resulting pure regional returns were:

Sydney: $\alpha+\delta_{\mathrm{S}}$

Melbourne: $\alpha+\delta_{\mathrm{M}}$

Brisbane: $\alpha+\delta_{\mathrm{B}}$,

with this procedure done quarterly over March 1995-June 2002 to generate the resulting series of thirty pure property sector returns and pure regional returns on both an equally-weighted and value-weighted basis. These two "pure" series will be compared with the standard PCA value-weighted return series.

The major benefits of this methodology are that the resulting pure sector portfolios have the same regional distribution as the PCA property index; similarly, the 
resulting pure region portfolios have the same sector distribution as the PCA property index. This decomposition methodology has previously been used for the diversification analysis for USA property over 1978-99 (Fisher and Liang, 2000) and UK property over 1981-95 (Lee, 2001).

The assessment of the relative impact of diversification by property type and geographic region will be done using a range of statistical procedures, including correlations and tracking error.

\section{RESULTS AND DISCUSSION}

\section{Development of pure PCA property series}

The justification for the development of the pure PCA property series is shown in Table 4 . The geographic distribution of the three property sectors is significantly different to the overall PCA index geographic distribution. For example, for retail, Brisbane is over-represented and for industrial, Brisbane is under-represented. Similarly, the property sector distribution of the three regions is significantly different to the overall PCA index property sector distribution. The resulting impact sees property sector returns having hidden regional components and the regional returns having hidden property sector components. This further reinforces the need for developing pure PCA property series to more effectively isolate the diversification contribution of the property type and regional effects.

Using the Heston and Rouwenhorst (1994) methodology, Figures 1 and 2 present the resulting quarterly property sector indices (office, retail, industrial) and regional indices (Sydney, Melbourne, Brisbane) respectively over March 1995 to June 2002 for:

- $\quad$ pure PCA: equal-weighted returns

- pure PCA: value-weighted returns,

as well as for the actual PCA value-weighted returns.

Table 5 presents a comparison of the PCA actual and pure return series over March 1995-June 2002 in terms of average annual return, annual risk and correlations. Whilst the differences in annual risks and average annual returns are not substantive (see Panel A) and the respective series are highly correlated (see bold correlations in Panels B and C), the pure PCA series are conceptually superior in more effectively assessing the relative importance of property type and regional diversification effects. 


\section{PCA PORTFOLIO: GEOGRAPHIC}

* Overall

- Sydney: $55.4 \%$

- Melbourne: $26.3 \%$

- Brisbane: $17.8 \%$

* Office

- Sydney: $57.5 \%$; distribution quotient difference $=+3.8 \%$

- Melbourne: $28.3 \%$; distribution quotient difference $=+5.6 \%$

- Brisbane: $14.2 \%$; distribution quotient difference $=-20.2 \%$

* Retail

- Sydney: $50.0 \%$; distribution quotient difference $=-9.7 \%$

- Melbourne: $25.0 \%$; distribution quotient difference $=-6.7 \%$

- Brisbane: $25.0 \%$; distribution quotient difference $=+40.4 \%$

* Industrial

- Sydney: $69.0 \%$; distribution quotient difference $=+24.5 \%$

- Melbourne: $23.0 \%$; distribution quotient difference $=-14.2 \%$

- Brisbane: $8.0 \%$; distribution quotient difference $=-55.1 \%$

\section{PCA PORTFOLIO: SECTOR}

\section{* Overall}

- Office: $56.7 \%$

- Retail: $37.5 \%$

- Industrial: $5.8 \%$

* Sydney

- Office: $58.9 \%$; distribution quotient difference $=+3.9 \%$

- Retail: $33.9 \%$; distribution quotient difference $=-9.6 \%$

- Industrial: $7.3 \%$; distribution quotient difference $=+25.9 \%$

* Melbourne

- Office: $60.0 \%$; distribution quotient difference $=+5.8 \%$

- Retail: 35.0\%; distribution quotient difference $=-6.7 \%$

- Industrial: $5.0 \%$; distribution quotient difference $=-13.8 \%$

* Brisbane

- Office: $45.0 \%$; distribution quotient difference $=-20.6 \%$

- Retail: $52.5 \%$; distribution quotient difference $=+40.0 \%$

- Industrial: $2.5 \%$; distribution quotient difference $=-56.9 \%$ 
Figure 1: Performance indices for office, retail, industrial sector: 1995-2002

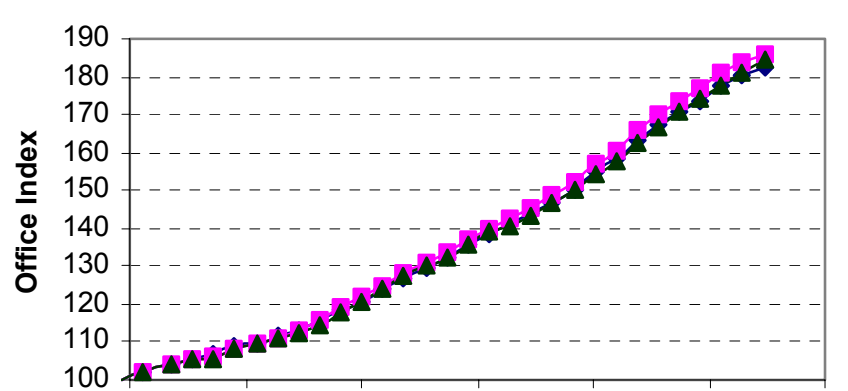

Jan-95 May-96 Sep-97 Feb-99 Jun-00 Nov-01 Mar-03

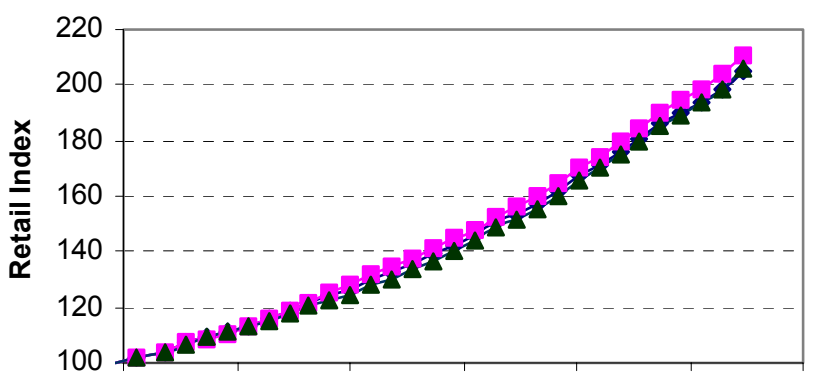

Jan-95 May-96 Sep-97 Feb-99 Jun-00 Nov-01 Mar-03

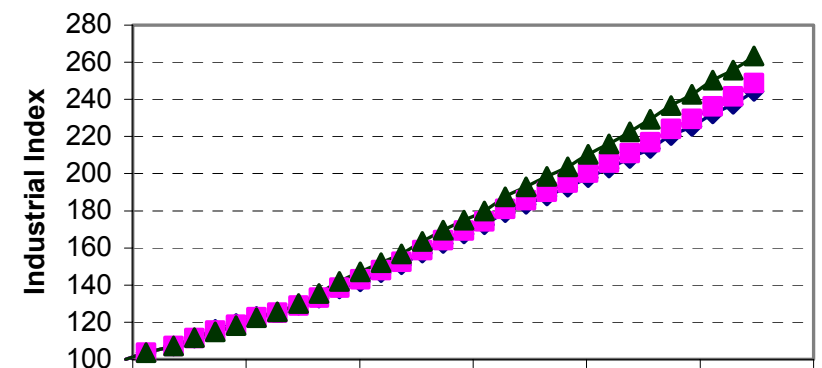

Jan-95 May-96 Sep-97 Feb-99 Jun-00 Nov-01 Mar-03

$\neg$ PCA Pure Equal-weighted - PCA Pure Value-weighted $\leftarrow$-PCA Actual Value-weighted 
Figure 2: Performance indices for Sydney, Melbourne, Brisbane: 1995-2002
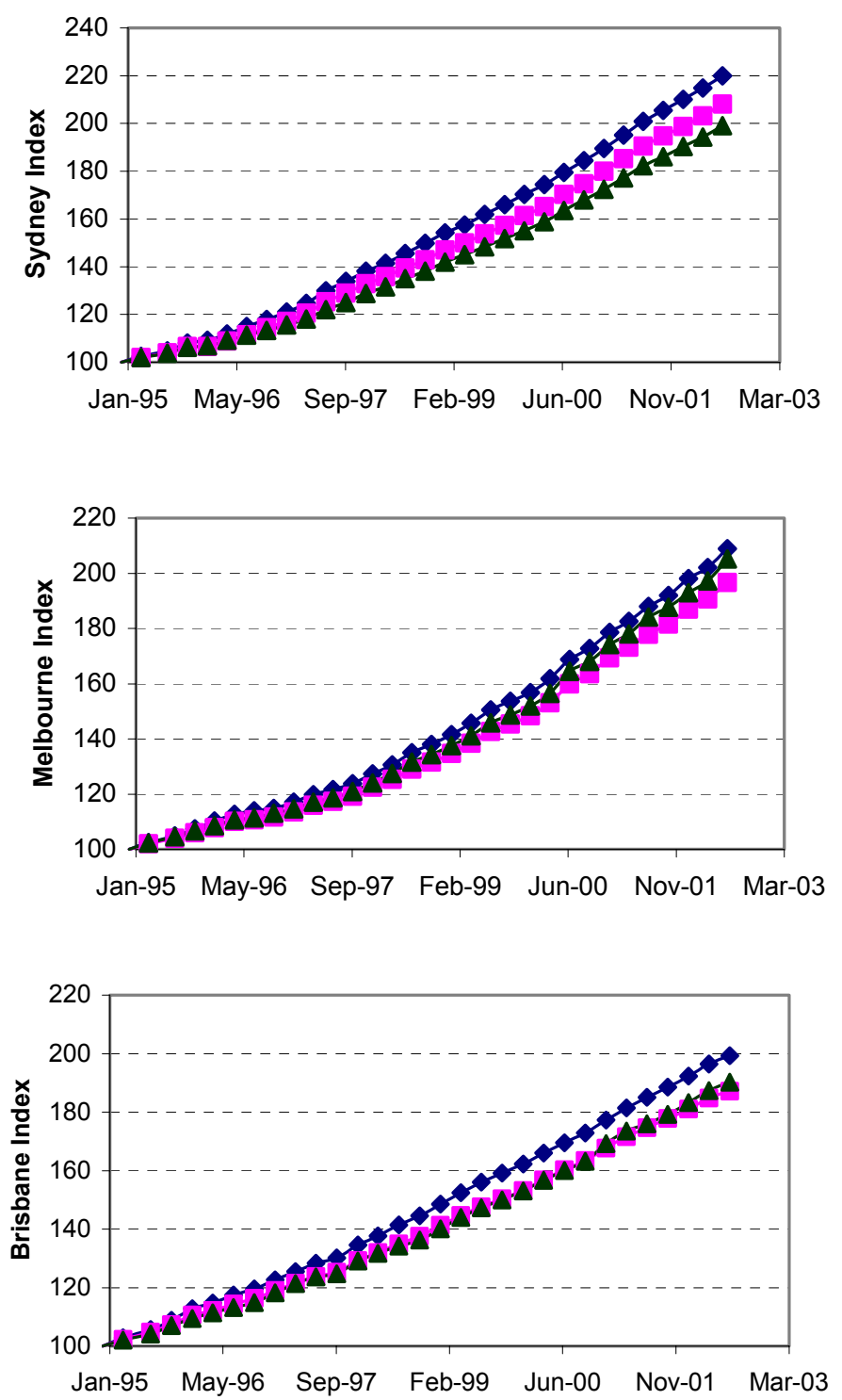

$\multimap$ PCA Pure Equal-weighted - PCA Pure Value-weighted - PCA Actual Value-weighted 
Table 5: Comparison of PCA actual and PCA "pure" return series:

1995 - 2002

\begin{tabular}{|c|c|c|c|c|c|c|}
\hline \multicolumn{7}{|c|}{ AND RETURN } \\
\hline & Avera & annual ret & & & inual risk & \\
\hline & $\begin{array}{l}\text { PCA actual } \\
\text { (value- } \\
\text { weighted) }\end{array}$ & $\begin{array}{l}\text { PCA pure } \\
\text { (equal- } \\
\text { weighted) }\end{array}$ & $\begin{array}{l}\text { PCA pure } \\
\text { (value- } \\
\text { weighted) }\end{array}$ & $\begin{array}{l}\text { PCA actual } \\
\text { (value- } \\
\text { weighted) }\end{array}$ & $\begin{array}{l}\text { PCA pure } \\
\text { (equal- } \\
\text { weighted) }\end{array}$ & $\begin{array}{l}\text { PCA pure } \\
\text { (value- } \\
\text { weighted) }\end{array}$ \\
\hline Sector & & & & & & \\
\hline Office & $8.49 \%$ & $8.34 \%$ & $8.60 \%$ & $1.24 \%$ & $1.13 \%$ & $1.25 \%$ \\
\hline Retail & $10.08 \%$ & $10.08 \%$ & $10.45 \%$ & $1.14 \%$ & $0.95 \%$ & $0.96 \%$ \\
\hline Industrial & $13.79 \%$ & $12.66 \%$ & $12.94 \%$ & $1.22 \%$ & $1.18 \%$ & $1.11 \%$ \\
\hline Geogra| & & & & & & \\
\hline Sydney & $9.62 \%$ & $11.09 \%$ & $10.28 \%$ & $0.99 \%$ & $1.01 \%$ & $1.28 \%$ \\
\hline Melbourne & $10.08 \%$ & $10.33 \%$ & $9.45 \%$ & $1.76 \%$ & $1.45 \%$ & $1.56 \%$ \\
\hline Brisbane & $8.96 \%$ & $9.63 \%$ & $8.72 \%$ & $1.22 \%$ & $1.02 \%$ & $0.90 \%$ \\
\hline
\end{tabular}

\begin{tabular}{lccccccccc}
\multicolumn{1}{l}{ PANEL B: SECTOR CORRELATION MATRIX } \\
\hline \multicolumn{7}{c}{ (1) } \\
AO & AO & AR & AI & POE & PRE & PIE & POV & PRV & PIV \\
AR & 0.22 & 1.00 & & & & & & & \\
AI & 0.11 & -0.07 & 1.00 & & & & & & \\
POE & $\mathbf{0 . 9 0}$ & 0.28 & 0.12 & 1.00 & & & & & \\
PRE & 0.18 & $\mathbf{0 . 9 6}$ & 0.00 & 0.21 & 1.00 & & & & \\
PIE & -0.25 & 0.08 & $\mathbf{0 . 6 7}$ & -0.14 & 0.12 & 1.00 & & & \\
POV & $\mathbf{0 . 9 5}$ & 0.17 & 0.21 & $\mathbf{0 . 9 6}$ & 0.12 & -0.23 & 1.00 & & \\
PRV & 0.41 & $\mathbf{0 . 8 0}$ & 0.18 & 0.29 & $\mathbf{0 . 8 7}$ & -0.07 & 0.35 & 1.00 & \\
PIV & -0.17 & -0.01 & $\mathbf{0 . 8 4}$ & -0.09 & 0.04 & $\mathbf{0 . 9 5}$ & -0.10 & 0.02 & 1.00 \\
\hline
\end{tabular}

\begin{tabular}{lrrrrrrrrr}
\multicolumn{10}{c}{ PANEL C: GEOGRAPHIC REGION CORRELATION MATRIX } \\
\hline \multicolumn{1}{c}{ AS } & AM & AB & PSE & PME & PBE & PSV & PMV & PBV \\
AS & 1.00 & & & & & & & & \\
AM & 0.35 & 1.00 & & & & & & & \\
AB & 0.10 & 0.12 & 1.00 & & & & & & \\
PSE & $\mathbf{0 . 8 2}$ & -0.04 & -0.02 & 1.00 & & & & & \\
PME & 0.28 & $\mathbf{0 . 9 1}$ & 0.31 & -0.12 & 1.00 & & & & \\
PBE & -0.28 & -0.10 & $\mathbf{0 . 6 3}$ & -0.18 & 0.16 & 1.00 & & & \\
PSV & $\mathbf{0 . 9 0}$ & 0.43 & 0.01 & $\mathbf{0 . 9 3}$ & -0.04 & -0.39 & 1.00 & & \\
PMV & 0.41 & $\mathbf{0 . 9 3}$ & 0.33 & -0.04 & $\mathbf{0 . 9 6}$ & -0.00 & 0.12 & 1.00 & \\
PBV & -0.10 & 0.05 & $\mathbf{0 . 8 0}$ & -0.14 & 0.27 & $\mathbf{0 . 9 3}$ & -0.23 & 0.19 & 1.00 \\
\hline
\end{tabular}

(1): AO, AR, AI = PCA actual office, retail, industrial: value-weighted portfolio POE, PRE, PIE = PCA pure office, retail, industrial: equal-weighted portfolio POV, PRV, PIV = PCA pure office, retail, industrial: value-weighted portfolio

(2): $\mathrm{AS}, \mathrm{AM}, \mathrm{AB}=\mathrm{PCA}$ actual Sydney, Melbourne, Brisbane: value-weighted portfolio PSE, PME, PBE = PCA pure Sydney, Melbourne, Brisbane: equal-weighted portfolio PSV, PMV, PBV = PCA pure Sydney, Melbourne, Brisbane: value-weighted portfolio 
Table 6: Sector and geographic diversification: correlation analysis: 1995-2002

PANEL A: PCA ACTUAL PORTFOLIO: VALUE-WEIGHTED

\begin{tabular}{|c|c|c|c|c|c|c|c|}
\hline Office & $\begin{array}{c}\text { Office } \\
1.00\end{array}$ & Retail & Industrial & Sydney & $\begin{array}{c}\text { Sydney } \\
1.00\end{array}$ & Melbourne & Brisbane \\
\hline Retail & 0.22 & 1.00 & & Melbourne & 0.35 & 1.00 & \\
\hline Industrial & 0.11 & -0.07 & 1.00 & Brisbane & 0.10 & 0.12 & 1.00 \\
\hline \multicolumn{4}{|c|}{ Average correlation $=\mathbf{0 . 0 8 8}$} & \multicolumn{4}{|c|}{ Average correlation $=\mathbf{0 . 1 9 1}$} \\
\hline
\end{tabular}

PANEL B: EQUAL-WEIGHTED PURE PORTFOLIO

\begin{tabular}{lccccccc}
\hline \multirow{2}{*}{ Office } & $\begin{array}{c}\text { Office } \\
1.00\end{array}$ & Retail & Industrial & Sydney & $\begin{array}{c}\text { Sydney } \\
1.00\end{array}$ & Melbourne & Brisbane \\
Retail & 0.21 & 1.00 & & Melbourne & -0.12 & 1.00 & \\
Industrial & -0.14 & 0.12 & 1.00 & Brisbane & -0.18 & 0.16 & 1.00
\end{tabular}

Average correlation $=\mathbf{0 . 0 6 2}$

Average correlation $\mathbf{= - 0 . 0 4 7}$

\begin{tabular}{|c|c|c|c|c|c|c|c|}
\hline Office & $\begin{array}{c}\text { Office } \\
1.00\end{array}$ & Retail & Industrial & Sydney & $\begin{array}{c}\text { Sydney } \\
1.00\end{array}$ & Melbourne & Brisbane \\
\hline Retail & 0.35 & 1.00 & & Melbourne & 0.12 & 1.00 & \\
\hline Industrial & -0.10 & 0.02 & 1.00 & Brisbane & -0.23 & 0.19 & 1.00 \\
\hline \multicolumn{4}{|c|}{ Average correlation $=\mathbf{0 . 0 8 7}$} & \multicolumn{3}{|c|}{ Average correlation $=\mathbf{0 . 0 2 6}$} & \\
\hline
\end{tabular}

\begin{tabular}{|c|c|c|c|c|c|c|c|}
\hline \multicolumn{8}{|c|}{ PANEL D: PCA ACTUAL PORTFOLIO: 1985-2002 } \\
\hline Office & $\begin{array}{c}\text { Office } \\
1.00\end{array}$ & Retail & Industrial & Sydney & $\begin{array}{c}\text { Sydney } \\
1.00\end{array}$ & Melbourne & Brisbane \\
\hline Retail & 0.52 & 1.00 & & Melbourne & 0.60 & 1.00 & \\
\hline Industrial & 0.71 & 0.33 & 1.00 & Brisbane & 0.59 & 0.57 & 1.00 \\
\hline \multicolumn{4}{|c|}{ Average correlation $=0.519$} & \multicolumn{4}{|c|}{ Average correlation $=\mathbf{0 . 5 8 2}$} \\
\hline
\end{tabular}

\section{Correlation analysis}

Table 6 presents the inter-sector and the inter-region correlations for the three portfolios (PCA actual and two PCA pure series) over 1995-2002, with average correlations used to assess the impact of the sector and region diversification. For the PCA actual series (see Panel A), an average sector correlation of 0.088 
compared to an average regional correlation of 0.191 indicates marginally better diversification benefits are delivered by the property sectors than regions. Importantly, with these average correlations close to zero, both property sectors and regions deliver substantial diversification benefits. However, as discussed above, these PCA actual series correlations do not provide the complete picture as they do not fully isolate the property sector and geographic effects; hence the need for this correlation analysis to also be done for the two pure PCA series.

For both the PCA equal-weighted and value-weighted pure portfolios (see panels $\mathrm{B}$ and $\mathrm{C}$ respectively in Table 6 ), the average region correlations were slightly less than the average sector correlations. The differences were only marginal, with both sectors and regions delivering substantial diversification benefits.

The above correlation analysis indicates significant diversification benefits for both property sector and region, with only marginal differences in diversification benefits for these two components in the portfolio. The average correlations seen for Australia over 1995-2002 were -.047 to .087, compared to average correlations of .68 to .75 over 1978-99 in the USA, with sector being seen to be more important than region in the USA (Fisher and Liang, 2000). These differences highlight two issues:

- the stronger diversification benefits provided by both property sector and region in Australia

- the impact of shorter time period of analysis for Australia (8 years) than USA (22 years); potentially not capturing the fuller impact of the longerterm property cycle. This is further demonstrated in the larger inter-sector and inter-region correlations for the PCA actual series over 1985-2002 ${ }^{1}$ (see panel D in Table 6) compared to 1995-2002, with average correlations of .519 and .582 respectively.

\section{Tracking error analysis}

Tracking error represents the standard deviation of excess sector or region returns relative to the overall PCA returns. As the PCA pure sector portfolio is diversified by region, a large tracking error of a pure property sector would indicate that regional diversification is less effective. Similarly, as the PCA pure regional portfolio is diversified by property sector, a large tracking error of a pure region would indicate that sector diversification is less effective (Fisher and Liang, 2000).

\footnotetext{
${ }^{1}$ This PCA analysis over 1985-2002 was done using six-monthly analyses (not above quarterly analyses), and industrial property just represented by Sydney (not Sydney, Melbourne, Brisbane as above); this was necessary due to limited PCA returns prior to 1995 .
} 
Table 7 represents the tracking error analysis for the three portfolios using both PCA benchmark portfolios over 1995-2002. For both the PCA pure equally weighted portfolio (see panel B) and the PCA pure value-weighted portfolio (see panel $\mathrm{C}$ ), the tracking error for the regions was larger than for the sectors. This confirms diversification by region is marginally more effective than diversification by sector. Again, the differences are only marginal, and the small tracking errors highlight the diversification benefits of both sector and region. Importantly, the results are consistent across both tracking error benchmark portfolios used in this study.

Table 7: Sector and geographic diversification: tracking error analysis: 1995-2002

\begin{tabular}{|c|c|c|c|c|c|c|c|}
\hline \multicolumn{8}{|c|}{ PANEL A: PCA ACTUAL PORTFOLIO: VALUE-WEIGHTED } \\
\hline & \multicolumn{3}{|c|}{ Sector diversified by region } & \multicolumn{4}{|c|}{ Region diversified by sector } \\
\hline Office & Retail & Industrial & Average & Sydney & Melbourne & Brisbane & Average \\
\hline Benchmark (1): .367 & .409 & .678 & .485 & .282 & .635 & 603 & .507 \\
\hline Benchmark (2): .358 & .393 & .705 & .485 & .281 & .613 & 602 & .499 \\
\hline \multicolumn{8}{|c|}{ PANEL B: EQUAL-WEIGHTED PURE PORTFOLIO } \\
\hline & \multicolumn{3}{|c|}{ Sector diversified by region } & \multicolumn{4}{|c|}{ Region diversified by sector } \\
\hline Office & Retail & Industrial & Average & Sydney & Melbourne & Brisbane & Average \\
\hline Benchmark (1): .351 & .374 & .726 & .484 & .469 & .524 & .666 & .553 \\
\hline Benchmark (2): .353 & .370 & .763 & .495 & .488 & .512 & .702 & .567 \\
\hline \multicolumn{8}{|c|}{ PANEL C: VALUE-WEIGHTED PURE PORTFOLIO } \\
\hline & \multicolumn{3}{|c|}{ Sector diversified by region } & \multicolumn{4}{|c|}{ Region diversified by sector } \\
\hline Office & Retail & Industrial & Average & Sydney & Melbourne & Brisbane & Average \\
\hline Benchmark (1): .406 & .326 & .675 & .469 & .505 & .516 & .549 & .523 \\
\hline Benchmark (2): .403 & .314 & .712 & .476 & .502 & .488 & .578 & .523 \\
\hline
\end{tabular}

* Benchmark (1): PCA “Australian” composite portfolio

Benchmark (2): PCA "Sydney/Melbourne/Brisbane" composite portfolio

\section{PROPERTY IMPLICATIONS}

Previous property diversification studies in the USA (Fisher and Liang, 2000) and the UK (Lee, 2001) have shown that property sector diversification is more important than regional diversification. 
This study has shown that the differences in property sector and regional diversification are not as substantive for Australian commercial property over 1995-2002, with regional diversification delivering slightly more diversification benefits than property sector diversification. Importantly, both property sector and geographic region deliver significant portfolio diversification benefits.

Particularly relevant in this Australian study is the more significant regional contribution to property diversification in Australia, compared to USA and UK. This clearly reinforces the institutional investment strategy of introducing sectorspecific LPTs in recent years and achieving portfolio diversification via regional diversification (as shown previously in Table 2). This has seen significant growth in the sector-specific LPT sector in recent years, with the 25 current sectorspecific LPTs accounting for over $\$ 29.2 \mathrm{~B}$ or $64 \%$ of the LPT sector market capitalisation at June 2002 (UBS Warburg, 2002).

Importantly, some institutional investors have included both diversified and sector-specific LPTs in their range of available property investment products. This includes AMP, Deutsche and Lend Lease. The success of this investment strategy is amply reflected in Table 8, which details the total return performance of LPTs, direct property, shares and bonds at June 2002 (PCA, 2002; UBS Warburg, 2002). This clearly shows the strong investment performance over these periods of up to ten years for sector-specific LPTs, relative to diversified LPTs, the LPT sector, and the stockmarket and bonds.

Table 8: LPT and direct property performance: June 2002

\begin{tabular}{lrrrr}
\hline & \multicolumn{4}{c}{ Average annual returns (\%) } \\
& 1 year & 3 years & 5 years & 10 years \\
\hline LPT sector & & & & \\
$\quad$ Diversified & $14.2 \%$ & $14.1 \%$ & $10.6 \%$ & $12.1 \%$ \\
Office & $13.3 \%$ & $12.6 \%$ & $8.8 \%$ & $10.7 \%$ \\
Retail & $17.1 \%$ & $13.4 \%$ & $13.5 \%$ & $12.5 \%$ \\
Industrial ${ }^{(1)}$ & $21.5 \%$ & $16.4 \%$ & $11.5 \%$ & $\mathrm{n} . \mathrm{a}$. \\
Total & $15.5 \%$ & $13.9 \%$ & $11.1 \%$ & $12.1 \%$ \\
Direct property sector & & & & \\
Office & $8.1 \%$ & $9.5 \%$ & $9.2 \%$ & $6.0 \%$ \\
Retail & $10.7 \%$ & $11.1 \%$ & $10.9 \%$ & $10.8 \%$ \\
Industrial & $11.6 \%$ & $12.1 \%$ & $13.2 \%$ & $12.3 \%$ \\
Total & $9.7 \%$ & $10.5 \%$ & $10.5 \%$ & $8.3 \%$ \\
Stockmarket & $-4.5 \%$ & $5.7 \%$ & $6.7 \%$ & $10.8 \%$ \\
Bonds & $5.6 \%$ & $6.2 \%$ & $6.2 \%$ & $8.0 \%$ \\
\hline
\end{tabular}

${ }^{(1)}$ : industrial LPT series does not extend for full period of ten years

Source: Author's compilation from UBS Warburg (2002) and PCA (2002) 


\section{REFERENCES}

Armytage, P. 2002. Property: challenging conventional thinking. Australian Property Journal 37(2): 82-88.

DeWitt, D. 1996. Real estate portfolio management practices of pension funds and insurance companies in the Netherlands: a survey. Journal of Real Estate Research 11(2): 131-148.

Eichholtz, P., Hoesli, M., MacGregor, B. and Nanthakumaran, N. 1995. Real estate diversification by property type and region. Journal of Property Finance 6(3): 39-59.

Fisher, J. and Liang, Y. 2000. Is sector diversification more important than regional diversification? Real Estate Finance (Fall): 35-40.

Hamelink, F., Hoesli, M., Lizieri, C. and MacGregor, B. 2000. Homogeneous commercial property markets groupings and portfolio construction in the UK. Environment and Planning A 32: 323-344.

Hartzell, D., Hekman, J. and Miles, M. 1986. Diversification strategies in investment real estate. AREUEA Journal 14(2): 230-254.

Heston, S. and Rouwenhorst, K. 1994. Does industrial structure explain the benefits of international diversification. Journal of Financial Economics 36: 3-27.

Lee, S. 2001. The relative importance of property type and regional factors in real estate returns. Journal of Real Estate Portfolio Management 7(2): 159-167.

Lee, S. and Byrne, P. 1998. Diversification by property type, region or function: a mean absolute deviation optimisation. Journal of Property Valuation and Investment 16(1): 38-56.

Louargard, M. 1992. A survey of pension fund real estate portfolio risk management practices. Journal of Real Estate Research 7(4): 361-373.

Mueller, G. 1993. Refining economic diversification strategies for real estate portfolios. Journal of Real Estate Research 8(1): 55-68.

Mueller, G. and Ziering, B. 1992. Real estate portfolio diversification using economic diversification. Journal of Real Estate Research 7(4): 375-386.

Property Council of Australia. 2002. Investment Performance Index: June 2002. PCA: Sydney. 
Property Investment Research. 2002. Annual Property Trust Review: 2002. PIR: Melbourne.

Seiler, M., Webb, J. and Myer, N. 1999. Diversification issues in real estate investment. Journal of Real Estate Literature 7: 163-179.

UBS Warburg. 2002. Real Estate Monthly Report (July). UBSW: Sydney.

Webb, J. 1984. Real estate investment acquisition rules for life insurance companies and pension funds: a survey. AREUEA Journal 12(4): 495-520. 